\title{
Karl Mattern: Mid-American Painter
}

Mary Mattern

Karl Mattern was born in Germany during the last years of the nineteenth century. He emigrated to the United States at the age of fourteen. After two years in the East he moved to the Midwest where he worked on a farm; later he lived in Colorado, Arizona, California and Kansas. From 1948 until his death in January, 1969, Karl lived in Des Moines where he taught in the art department at Drake University.

Karl Mattern exhibited his work continuously for over fortyseven years in national and local exhibitions. He painted nearly every day of his life. The following is an excerpt from "The Practised Hand, " an unpublished manuscript written by his wife, Mary.

\section{Karl Comes To America}

FOR HIM, AT THE AGE OF FOURTEEN, going to America meant Indians, adventure. It was the land where the expert marksman, Shatter-hand, had lived in the fiction of his childhood (years later he and George Grosz were to compare notes on what their reading about Shatter-hand had led them to expect of America). For Eva Mattern, his widowed mother, Karl's going to another place was an economic necessity and the best thing, she thought, for the eldest of her four children; best for the three younger ones who would now have more. America was not quite the land where the streets were paved with gold, but it was the country of unlimited possibilities. For a year and a half after her husband's death in January, 1905, she had corresponded with his relatives in New York. They were, from their letters, doing well, very well. They urged her to send Karl to them. Aunt Katie would meet the boat, would look after him.

He sailed for the United States with a friend of his family, an Oklahoma farmer who had been visiting relatives in Germany. They 
arrived in New York in August, 1906. After an hour or so Jake, the farmer, disappeared. Karl was not to see him again for two years.

There was no one to meet him. Aunt Katie was nowhere in sight.

The officials were very kind at first, but then, after an hour of waiting they were impatient and suspicious. He could hear their words, but he knew no English. They whispered together and stared at him. Finally one of them said in bad German, in a very loud voice, "My boy, if your aunt doesn't come soon we'll have to send you to the Island."

The immigration officials left the ship's dining room, probably to arrange for his being sent to the Island. He heard someone coming down the stairs and full of terror he looked up to see Aunt Katie; he knew her at once from her photographs.

The ship had docked at seven; it was noon when Aunt Katie appeared; this Karl remembered all his life, but of the hour or so afterwards he remembered little. They went by elevated uptown to 113th and Park where Aunt Mary (his father's sister) and her husband, Uncle Hugo, lived in a railroad flat. Aunt Katie, with whom he was to live, was in the process of acquiring a boardinghouse and she also was staying with her sister. The flat was narrow, had too few windows, and too many people. There was a boy cousin just his age and two girl cousins. For the week or so Karl stayed, there were seven people in the five rooms. His Uncle Hugo told him there were three thousand people living in that one block. That was in 1906. Of course the neighborhood was clean then compared to now. But compared to where he had just come from it was terrible.

The food was terrible, too, especially the bread; for Karl a good bread will make a mediocre meal satisfying and an excellent meal with good bread superlative. It was possible then, with little effort, as it is today, to buy better bread in Manhattan than any place else in the country, but the taste of his relatives, like their speech, had become corrupted: they spoke a strange mixture of American and German.

He was very homesick that first night and somewhat dazed. The next morning he left the flat, noting its position in the house and the position of the house from the corner, took the elevated and rode around Manhattan. The following day he went down to the Battery and saw the ships come in. He lost his homesick feeling. He never lost his insatiable curiosity about city and country shapes; trees, buildings, clouds, people; all man-made forms, and those of nature. 
After a week's stay at Uncle Hugo's, the boarding house Aunt Katie expected to be a great financial success was ready for occupancy, at Vanderbilt and Waverly in Brooklyn, and she and Karl moved there. During that first week Uncle Hugo had scanned the want ads for Karl, had talked to people in the saloon where he tended bar. Was there a job for a bright hard-working boy? Karl was somewhat confused about one job possibility Uncle Hugo had heard about: if the job were available Karl would work in a gleaming interior where there were many precious shiny objects. In his roamings one day Karl looked through a large plate glass window at shiny white objects with metal fittings; bath-tubs, wash-bowls, toilets. Was this the place where he might have his first job in America? Months later he found out that Uncle Hugo had been talking about Tiffany's.

In the meantime Karl found a job in a lithograph house. At the Robert Gaer Company under the Brooklyn bridge he carried paper to and from the press, and after a short time was advanced to grinding lithograph stones. He worked from 7:30 A.M. until 5:30 P.M. with a half hour lunch period and his pay was $\$ 5$ a week.

At Aunt Katie's things were not going well. She was a poor cook and manager; she had no understanding of the spirit or needs of a fourteen year old boy: she expected Karl to wash dishes every night, do various cleaning jobs. He had little time for anything but work at his job, work at the boarding-house, work at night school where he was learning to read and write English. His unhappiness, his restlessness and discontent were taken out in moving from one job to another. In the two year period before he left New York he had four jobs, many workless weeks.

Finally Karl wrote to Jake: Could he come out and work on the farm? Jake wrote back that he could, and sent him the fare. After all, Karl thought, maybe I'll be a farmer like grandfather. Maybe I'Il find out what I can do besides draw. I've got to learn to do something. He was sixteen years old when he left New York. He had never been to an art museum; he didn't even know the Metropolitan existed. At school, in Germany, drawing had been part of the curriculum; instruction had been thorough, but rigid. At home Karl drew constantly, everything in sight. His parents had neither discouraged nor encouraged him. Years later, when he was past forty, Karl went back to visit his mother, and she gave him the drawings she had cherished for twenty-seven years. Several of them 
more than hinted at the sort of landscape composition which was to be developed after many years of painting. But now at sixteen on his way to a farm on the Kansas-Oklahoma border Karl had no thought of becoming a painter: his need for food and shelter, his ignorance of any other world than the one he had been brought up in, the world of the farmer, the tradesman, the skilled worker, was absolute. $\mathrm{He}$ had a need to be adequate or very good at something, but that he could or would enter the world of picture-making never came into his head.

$\mathrm{He}$ led a hard and lonely life with Jake on the farm: for ten dollars a month, a bed of corn shucks, meals of fried foods, he helped to plow the two hundred acres of wheat fields, mend fences, feed horses, cows, chickens, hogs, haul hay, grain, turn virgin soil with a sod plow. Once a month Jake and Karl walked a half mile to a neighbor's for a game of cards. There Karl was always being compared to the son of the house who was a better farmer than Karl, stronger physically, less given to silences, to day-dreaming. Karl was again made painfully aware that he was different and inferior. In New York at Uncle Hugo's he had been compared unfavorably with his cousin Ferdinand who was, they said, going to be a smart business man someday, and make a lot of money.

The neighbors were never asked to Jake's house because Jake had very little furniture. Jake had built two small cabins; one had a stove, a table, two chairs, and the bed where Jake slept; the other, a two room cabin, had nothing in it but the sack of corn shucks on the floor where Karl slept (months later Jake harvested a field of oats for the first time, and since he had no storage place for this crop it was put into the other room of the cabin).

On holidays Jake's brother and his wife asked Jake and Karl to dinner and once in a while Mrs. Wetz baked a loaf of bread for them.

About twice a month Jake's young nephew, John, who was about two years younger than Karl, rode over on his pony to see Karl; in the summer John came with other farm boys and they swam in the creek. Most of the time Karl was left in charge of the farm while Jake went away on business, or diversion-Karl never knew which.

On one of these days alone a beautiful unhaltered, unbridled horse came trotting down the road, and turned into Jake's gate. Karl patted the black, quivering animal, put a halter on him and tied him to a post in the corral, then went about his chores. A few minutes 
later two men came running down the road; they shouted, "Have you seen a black stallion?" Karl led them to the corral. They explained, with respect in their voices that Karl had been dealing with a vicious animal, that he had taken an awful chance, that he was a brave kid. They wouldn't accept Karl's protestations that he had no idea the horse was dangerous, and before they left the man and his son gave their names, invited Karl to dinner for the next night.

Karl recognized the name as that of Jake's dangerous neighbors; damned and dangerous because they were monsters, they were Democrats. The next night Karl had dinner at the enemy's house and had a warm wonderful time, the best he'd had since he came to this strange country, where, he thought as he walked slowly home to his hard bed of corn shucks, gentle, kind people were not recognized as fellow human beings because they voted differently, thought differently. Would he, when he was a full-grown man, narrow the world to that of his beliefs? And did he now have any beliefs? Not many. He did know, though, that he wasn't going to be a farmer, and a few days later he told Jake he was leaving.

Jake drove him to Kiowa where he spent a few of the fifty dollars he had saved to take a train to Great Bend, Kansas where he wandered around looking for a job, any job. There were none, but in the course of hunting he met a burly red-headed bum who introduced him to the science of riding freight trains. Karl walked twenty miles from Great Bend to Hoisington, Kansas. There he rode his first freight to Pueblo where he got a job as a muleskinner on the Turkey-creek dam. After a month he had had enough of that job and a small stake to go on to Denver. With little money to wait for a better job, Karl had no choice but to again go out on a road job in the mountains. The weather now was more temperate, the contract more generous so that he fared better for money and was able, when he returned to Denver, to look for work at a more leisurely pace and still eat, pay room rent.

Now, for the next two years, through various jobs and in different rooming-houses he met people of his own age. From 1909 to 1911 he had many casual acquaintances, but for two men, they left no impression on him. One of the men was a drunken illustrator who lived in a room next to Karl's and who during his two or three relatively sober days of the week did his magazine drawings and talked to Karl about them. He was a hack, but he opened a different 
world to Karl. He talked to Karl, he showed him reproductions. Karl began to wish for larger worlds, and then he discovered that there were original paintings to be seen at the museum. The next move was natural: he began to draw again, and to find that he needed to learn much.

His needs then (and always) were simple; food, a place to sleep, a change of clothes, a glass of beer with a friend; he earned enough, and a bit more, to supply these in his first Denver job with a firm that made everything, from rubber stamps to campaign buttons, to bronze bank signs. He was the mechanic, the salesman, the manager. By the time he began to study drawing he had transferred to a better paying job with a firm making surveyors' instruments. There he also did many jobs, but they were more interesting and demanded some skill. After a quick evening meal he hurried to the home of the man who was his first drawing teacher in America. He, too, was an illustrator, and a hack, but he took Karl from where he was as a draughtsman when he left Germany, much further; so far that this Denver teacher said, after a few months, "You'd best go on to a good school, say the Chicago Art Institute. I've taught you all I know. You can, you ought to learn more than I can teach you."

\section{Training}

A few days later, with twenty-five dollars in savings, Karl left for Chicago and there discovered immediately that he didn't have enough money to live on and go to school. After a succession of unsatisfactory job situations, he enrolled at the Chicago Art Institute. His first teacher in the first class, a drawing class, was very young, very rigid. He talked through his teeth as he criticized each drawing made from a cast; neatness, conformity were emphasized, were good; a student who did not draw in the prescribed way was a bad student. Karl had no idea then that he was going to be a painter-teacher for the greatest part of his life. Then he vaguely wanted to be a cartoonist; he might paint a little, but the major part of his time would be spent making a living, and that would be at what he thought he liked: cartooning. A cartoonist should draw well; the ones he liked did. He conformed to what the teacher in this class wanted; this he did because he was shy, because he believed teachers knew more than their students, and that the student should get as much as he could from the teacher. And yet a small rebellion was in him. If I were a teacher, he thought, I'd let a student draw in 


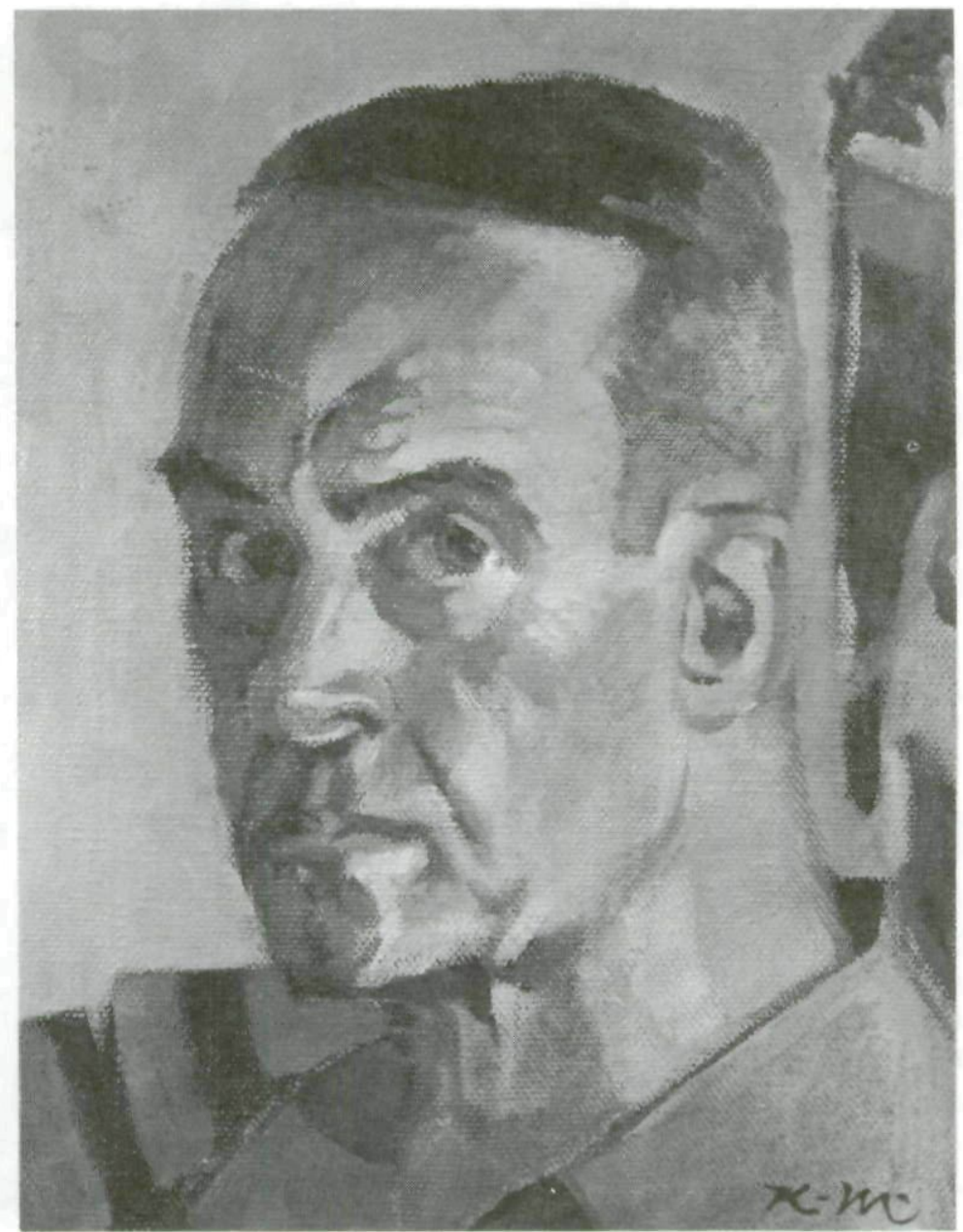

Courtesy of Author

Karl Mattern, self portrait, 1959, oil painting.

his own way as much as possible. Why shouldn't he so long as he made a good drawing? Years later, as a teacher, he encouraged students to find their own way; he discouraged imitation and conformity; he tried to carry the student from where he was to where he wanted to be or should be, according to this talent.

During the first years of the eight or nine years that Karl went intermittently to the Chicago Art Institute he had many jobs which 
entailed hard physical labor. As his need for more time and energy to devote to painting increased, he desperately sought jobs which would leave him less exhausted after an eight hour day, able to paint more. He eventually turned to hack work for commercial art firms. He was not, he knew even then, very good, but he was adequate. During these monotonous jobs he met many commercial artists who talked wistfully of someday devoting their time to what they called real painting and who envied Karl his dedication, his being able to do real painting in the spare time which they could never find.

Karl had, in his wandering, odd-job years, made many acquaintances, many casual friends, but he believed fundamentally that he was a loner. He had no close friends. Years later, looking back at this period, he understood why he thought he got along better without any close friendships. He had little in common with the young men and women he met up to the age of twenty-five except youth and the longings of youth; their longings were not his; his were, he knew, from their talk of the future, too different and incomprehensible, too remote from the world they lived in. They would listen; but they would think him a nut. He had tried it so he knew.

Shortly before the United States got into World War I Karl met and made his first close friend, Bertram Elliott. Karl was then about twenty-five, Bert a year or two older. Bert was a very handsome, brilliant young man who had majored in entomology, was interested in drawing, had social graces which, because they belonged to a very intelligent man, impressed Karl who up to then had naively assumed that social polish was a concomitant of superficiality. Karl's thorniness was lessened: Bert and people he met through Bert made it quite clear that they too lived in Karl's world and furthermore respected, admired Karl for his dedication to painting, his fresh eye, his quickness to spot the ridiculous, the phony.

Bert and Karl's friendship (with mine added in 1922) continued until Bert died in New York, in the summer of 1931. We had been apart geographically, except for two short visits, for many years, but our affection never diminished; it increased through our frequent and openhearted letters. Because of Bert's confidence and interest in him Karl took his advice and went back to the Art Institute where he was fortunate enough to work and study with George Bellows. He had some doubts, at first; there were many Bellows' he liked, but there were an equal number he disliked because he thought they were too chauvanistic, were almost illustrative. Bellows as a man and 


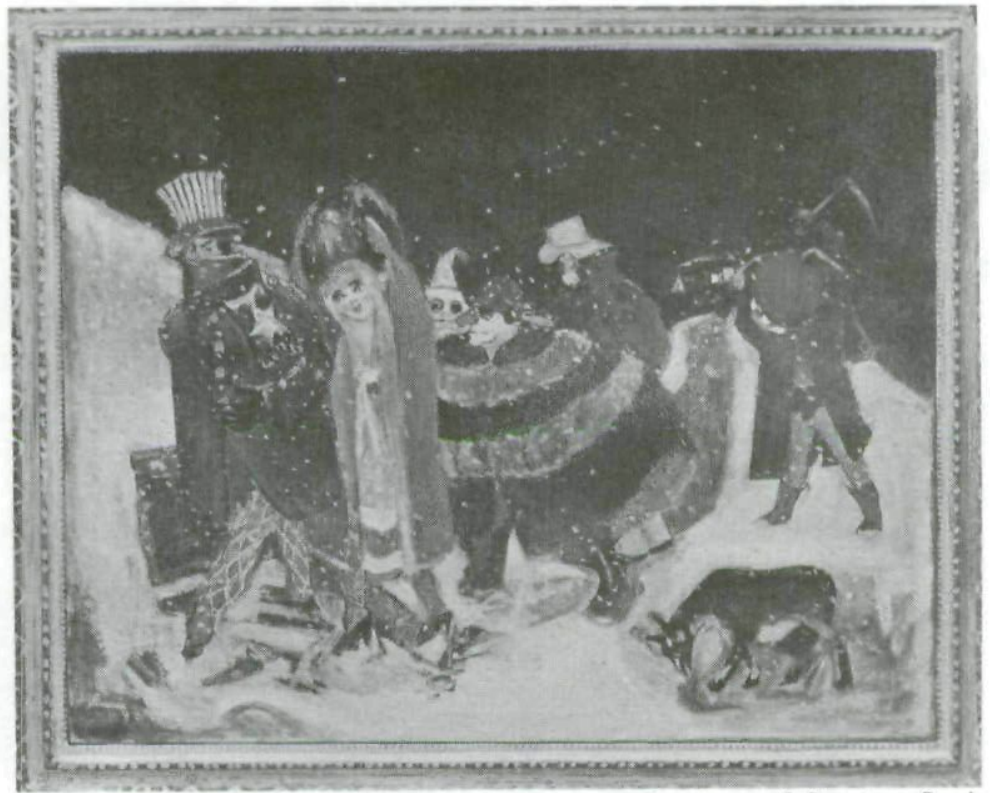

Courtesy of Brenton Banks

The Troupe in Winter, 1966, oil painting by Karl Mattern.

as a teacher not only dissolved his doubts, but won Karl's admiration, respect and affection. Karl learned more from this teacher in a few weeks than he had from other instructors in months. One afternoon Mr. Bellows asked Karl if he would accompany him on a tour of his show, that he would like Karl to speak frankly about the paintings. Karl did. Bellows agreed with almost everything Karl said. Karl was afraid he had been too blunt about the paintings he didn't like, scanty in his praise of the ones he did. Bellows, extremely sensitive, in the best meaning of the word-sensitive to others' feelings-quickly felt Karl's fear and reassured him. He said that so far the only painting he really felt was successful was the portrait, "Cross-Eyed Boy." "Aunt Fannie," now at the Des Moines Art Center, another excellent portrait, had not yet been painted. Many years later Karl said, "It just now entered my head that George Bellows was only ten years older than I was. I expected too much from a painter under forty. George Bellows was not the greatest painter of his time, but a very good one, and a most accomplished draughtsman (via lithography) and wielder of the brush. He was a charming man, a wonderful teacher, 
and he had absolute integrity. What more can one ask? He had his limitations, but who hasn't? Even the great painters had theirs."

For fifty years, long after other papers were destroyed, Karl kept the invitation to a dinner in honor of $\mathrm{Mr}$. Bellows given by the students. The fee was to be between $50 \notin$ and $\$ 1.00$, and this Karl could not afford to pay. Incidentally, if the tuition at the Art Institute had been raised by five dollars per term he would not have been able to attend. In all the years of his life he never had a scholarship, a grant or fellowship of any sort.

In $1921 \mathrm{Karl}$ exhibited for the first time. This was in a group show at the Arts Club of Chicago; there were twenty-seven painters represented by sixty-six works.

The show was reviewed by Carl Sandburg; Bert Elliott's work was reproduced. Of the twenty-seven painters few, over the years, continued to paint, to exhibit. Every three years when we checked catalogues for recent material to send to the new edition of Who's Who In American Art we were astounded at the mortality rate: painters who were prominent, painters who were lauded, who won huge awards had vanished, never to be heard of again.

In 1922 Karl exhibited at the "Chicago and Vicinity" show and received his first notice in a national art magazine, The Arts, one of the better magazines then and now.

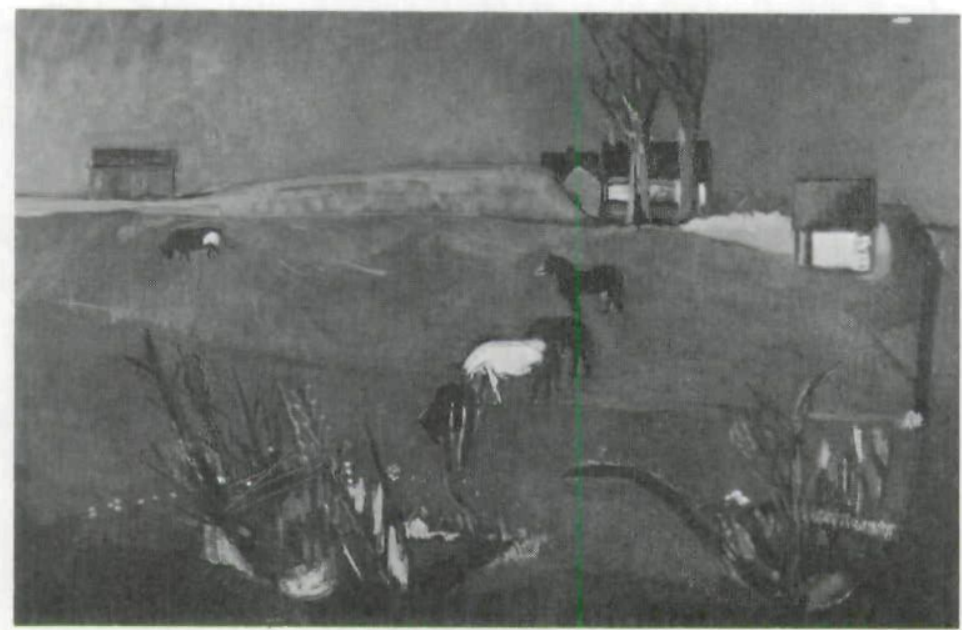

Courtesy of Brenton Banks Green Landscape, 1951, oil painting by Karl Mattern. 


\section{Lawrence, Kansas}

Three years later we were in our first house with our own furniture. In those three years, we had lived in Denver, in a horrible light-house-keeping room where the landlady bawled us out if we turned the lights on before it was pitch-dark; in Arizona in a little shack on stilts (it had been moved from another location) meagerly furnished by our landlord with a bed, two chairs, a table, a wood-burning stove, and two oil-lamps (no curtains); in California where first we had a bleak apartment with an inner-door bed and an overstuffed sofa (there were apartment-style curtains, ecru lace panels which added to the depressing effect); and in a little furnished house in South Pasadena about which I remember little because it was summer and we spent most of our time outside.

In the summer of 1922, a few months after we were married, we met the painter Albert Bloch who had just returned from Munich. This meeting, other meetings, began a friendship which more than any other was to direct and change our environment for twentythree years.

We had heard from painter friends that the then famous Albert Bloch, member of the Blue Rider group* was in Chicago, that he was inaccessible, there was little chance of meeting him; he had snubbed all but a few overtures. This talk was part of casual studio gossip and lingered on in our memory only because of what happened shortly after the tellings.

Karl was teaching at the Fine Arts Academy, so was Bloch. They had passed each other in the corridors with curious glances, but no greetings. One day Karl had a canvas under his arm which he was storing for an hour or so in the cloakroom until he could enter it, after teaching hours, in a current Chicago show. When Bloch went to the cloakroom he saw the painting. He mentioned it to a friend as being the only painting he'd seen by the contemporary group of painters in Chicago which had interested him; he'd like to meet the painter; his friend was ours so it was easily arranged. We met at the

*The Blue Rider (Der Blaue Reiter) 1911-1914 was a German expressionist group in Munich which included Klee, Kandinsky, Make and Marc. Marc and Make were killed in World War I. Kandinsky, Klee and Bloch remained friends all their lives. A painting of Bloch's done in Munich in 1914 is in the collection of the Des Moines Art Center. 
large loft where Karl painted. Bloch praised everything; Karl was somewhat over-awed by the many, positive statements about what was wrong, what was right about all other painting.

We saw Bloch frequently until he left for the University of Kansas where he was to head the painting and drawing department. For the next three years, while we moved to Denver, to Arizona, and to California, we heard from him now and then. In the late summer of 1925 he offered Karl an assistant instructorship.

We were fed-up with California, we were quite literally underfed. Karl and I had been doing odd jobs for a trade magazine (Karl the drawings, I the cut-lines); the work was irregular and paid just enough to keep us eating meagerly. Now and then Karl got a job as an extra in the movies. We were barely able to pay the rent and the utilities. The constant search for work left little time for painting.

Karl wrote to Bloch accepting the job. We could hardly wait until the Dean approved Bloch's recommendation. Bloch was a painter Karl admired; he could work for a man who was, he believed, an artist as well as a good painter. Although Karl was at this period, a solitary, he had had in Chicago some meetings and talks with fellow painters; he had missed this more than he thought he would. Now he could have a fairly close association with a man whose work and direction he liked and understood.

In August of 1925 we were on our way back to the Midwest. Bloch praised the few water colors Karl had made in Arizona on the rare days he had off from running a Texaco filling station (the promise by the manager, a former fellow-student of his at the Chicago Art Institute, that he would have every week-end off had been broken; painting time was sparse). He praised the California work, the Denver work. Karl was at first, as he had been in Chicago, awed by Bloch's positive statements.

During the next few years Karl produced much and Albert Bloch told him that everything he painted was superior to almost everything else painted in the United States. Even the fact that Karl was continually showing in exhibits all over the country, sometimes winning prizes, did not convince him that Bloch's praise was other than somewhat fullsome; after a while he ceased to take what he came to know was a less than objective attitude on Bloch's part, too seriously.

Albert Bloch did give Karl much for which he was always 


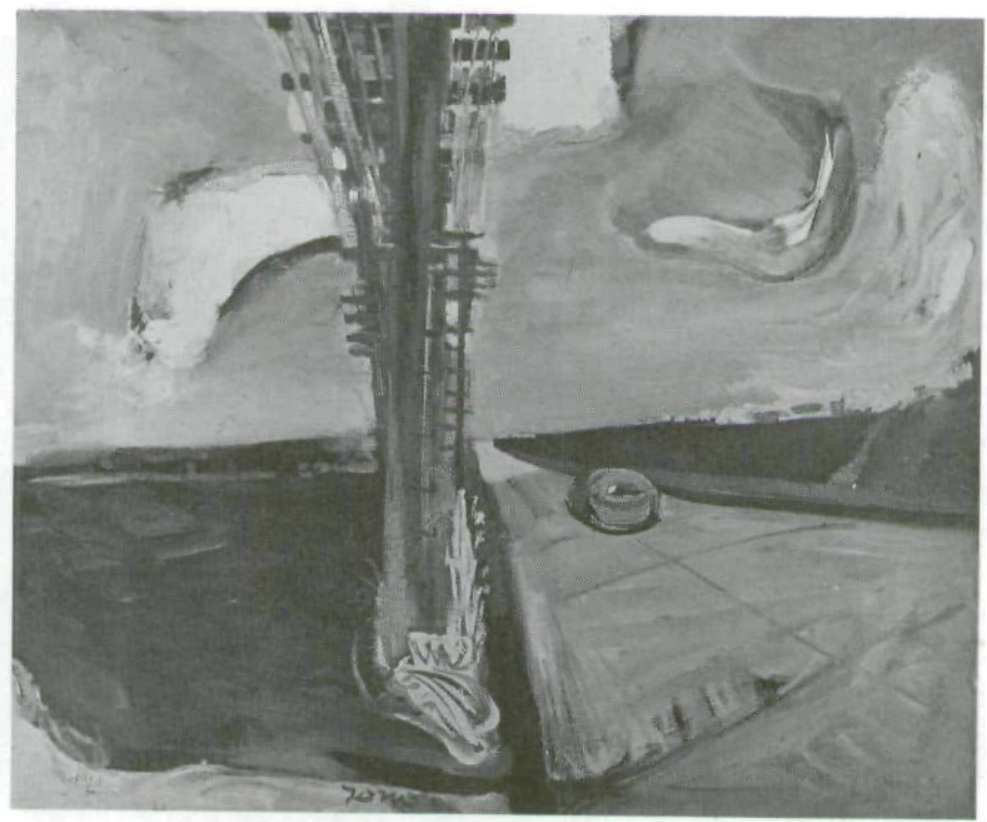

Courtesy of the Des Moines Art Center

American Highway, 1952, oil painting by Karl Mattern.

grateful; he gave him confidence in his own work at a crucial time. Karl never ceased to admire Bloch's integrity, his impatience with shoddy work, shabby ideas and his bitter contempt for those who produced this. There was no compromise in him. His ferocity was hard to live with but one had to respect it; permissiveness was all too common.

We seemed to have lots of time in the years in Lawrence where Karl taught at the University of Kansas; the first years we were always looking forward to something, a week, or a month, or a semester in the future. There wasn't much to do in the town itself except to go to a movie, and we despised most of the movies. We made a few friends on the faculty; those who we thought were interested in the things we were. We had parties for them; they had parties for us. We played card games, we danced, we drank abominable bootlegged liquor, we talked and argued a great deal. We were young and full of energy, and there wasn't enough to do in a small college town that could use up half of it. Both of us had 
always read much; we read more. We walked back and forth from the small Carnegie town library and the large University one, carrying books which we devoured rapidly. The art department had a few shows; we saw them. The art museum had collections of clocks, furniture, glass, creches, china, and a few very good paintings.

We went to Kansas City, forty-five miles away. There wasn't much in Kansas City the first few years; later there was a symphony, and the Nelson Gallery.

We seemed to have a very narrow social life. We read more and more. We talked together, the two of us, more and more. We were thrown upon ourselves. Karl's teaching was leisurely before the war, before the veterans started coming to the University. He would come home for lunch three days during the week-days, and paint most of the afternoon. On Saturdays and Sundays he drew or painted half the day. For many years he had the large studio at the University to himself several afternoons a week and he could paint there. In some years when the studio was also the office of the art department he painted in the make-shift studio at home (we never had enough money-salaries were very low-to make a down-payment on a house where we could build an adequate studio), or in fine weather he would make water color paintings out-of-doors.

There were very few people Karl could talk to about painting, even the little bit that he felt could be put into words (he was not a talker on aesthetics, anyway); so what ideas he had, or evolved during the years in Kansas, he talked to me. I don't believe that a day passed during our twenty-three years there when somethingsometimes a lot, sometimes a little-wasn't said about the art of painting or the history of painting. At first I just listened, gradually I asked questions; at first it was a foreign language; when I believed I understood the words I began to transpose them into literary terms. Soon I knew that this was wrong. I dimly sensed what Karl was trying to tell me: one could not really convey or explain painting, except in an abortive way, with words; painting was for the eye, and the eye learned from looking; words to explain the experience were inadequate. But was it possible, I asked Karl, (and I asked myself), over and over again, to look at painting without verbalizing, without all sorts of deeply-rooted preferences and dislikes dictating one's attitude toward the color, the subject matter? Not at first, was the answer, and maybe never for many people. 


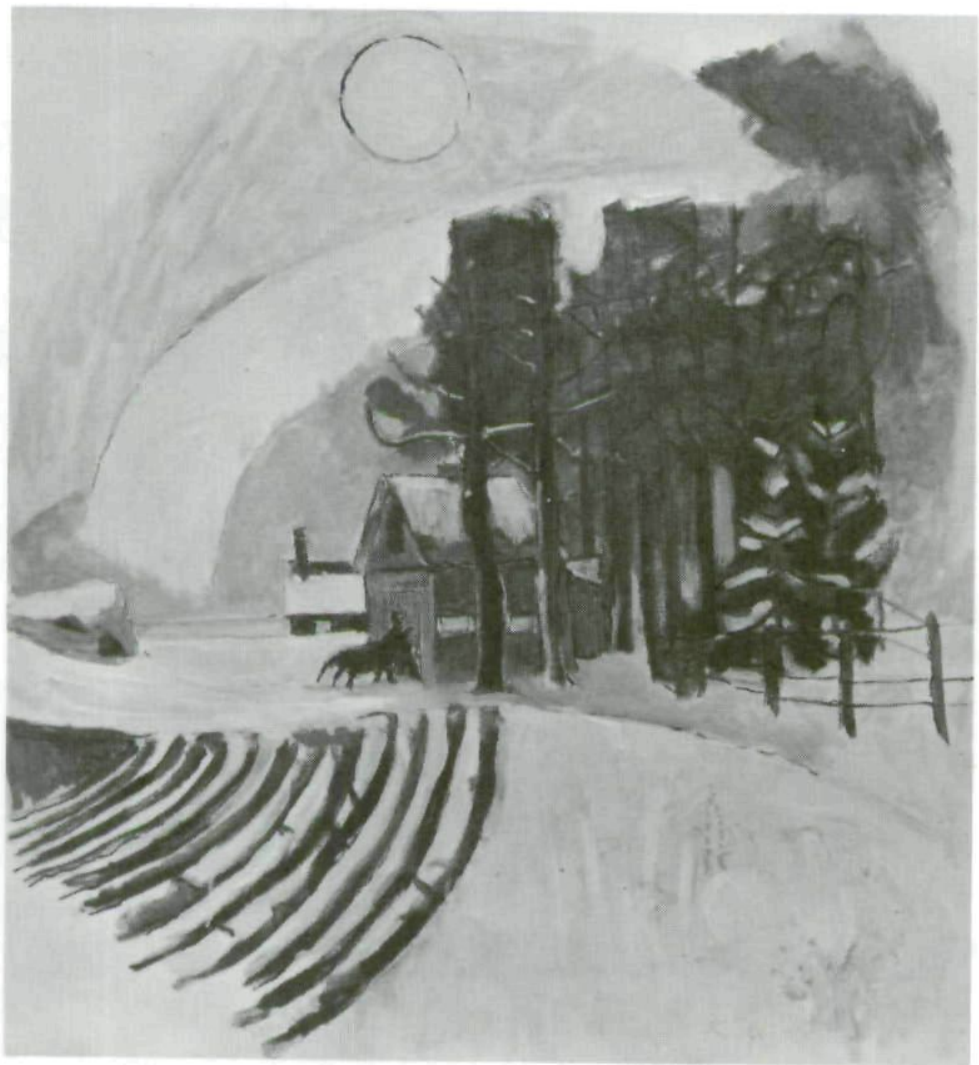

Courtesy of Robert Speed

December 1968, oil painting by Karl Mattern.

The most important thing, Karl would say, was to truly observe; I tried to and sometimes did; so that I learned, or rather I saw that grass wasn't always green during the green season, and the skies were other than gray and blue, and shadows weren't always black. Then there were shapes of clouds, cows, people; and light, the time, the closeness to other shapes altered them. The visible world which I had moved through believing I really saw and delighted in became enlarged constantly; and so did my joy in discoveries. I, a city girl, who thought of herself as being a lover of nature, a sensitive observer, found that I had been, and probably would be, for a long long time, a word-mouther, and mostly unseeing in the world of color, substance and shape. 
In Lawrence there was lots of time; more than we had ever as adults had, and it was there because Karl had a fixed amount of money coming every month. We had had time before in the sense of hours when we weren't working, but our minds were not free to enjoy this; we were too worried; that was in California, in Denver. In Arizona where he ran a filling station the only time Karl had, and that only rarely, was Sunday; by Sunday he was so exhausted from the hard physical labor of the days before that he could only sleep and eat to rid himself a little of piled-up fatigue.

We didn't know until long afterward how much the many years in Lawrence had done for us. We went on little trips during the summer to Chicago, to Denver, Wichita; stayed for a few days, a week or two (we felt we needed the replenishment of the larger cities, and we chose those close to us geographically because we hadn't the money for further travels); they all had places where pictures could be seen, where there were friends who painted.

We arrived in Des Moines in 1948. Karl had an offer from Drake University a year before he was due to teach there; it sounded good for we would be in a medium-sized city, we could get away from the gown atmosphere to the town, if we wished. There would be a somewhat different landscape to paint (Karl said, later, "In lowa the trees grow straight. In Kansas the wind blows twenty-four hours a day on weekdays, forty-eight on Sundays; no wonder Kansas trees are bent and crooked"). Some of this may have been a rationalization: Karl often contended that subject gets in the way in the art of painting, is often of no importance. "To the illustrator the subject is the only reason for painting."

Anyway whatever the reasons we were glad to live in a different place. The next twenty years were to be the most productive years for Karl, and in many ways the happiest; the doubts, the storms of youth were over. He knew his limitations as a man, as a painter.

The world of trees, fields, weeds, clouds, cows, snow, flowers, pigs, horses, buildings, people, fruit; all the visible world was his material; his content. Form was not enough for him; but form and content fused. Weather is always there, in his landscapes.

Some years ago a graduate student wrote, and among other things, asked him for his credo. He answered:

The art of painting consists primarily of inventing a world of a given dimension. If the painting is successful it then may be called a picture. 
To paint a successful picture one must put into it all one feels and knows. I've never been able to separate the various procedures, to catagorize them: painting, drawing, coloring, texture, etc.; since separately any one of these would not make a picture.

\section{Des Moines}

He worrried at Drake, as he did everywhere he taught, about his students. He felt that the system of education now prevalent was inadequate: no sooner did a painting student get started in class than the time period was over. The three times a week painting classes were not enough. He felt serious students (alas too few) should paint every day. It was, naturally, the serious student he worried about, he talked to. He would say, "If you want to be an artist be prepared to push everything else aside. You have to have extraordinary devotion to your work. You can't monkey around."

Certain words got Karl down. One of these words was creative and the phrase which he felt was redundant (and it is) was creative artist. The more fashionable word he despised was creativity. A neighbor of ours told us, proudly, that her husband was full of creativity; he had made a small book shelf.

We were to hear much about child art and we were to hear more, and to know many amateur painters. Many of them knew they were amateurs and had no pretense; others after a year or two of training felt they knew as much and painted as well as professionals. When this did not irritate Karl it amused him; his amusement was greater than his irritation. He believed that the education of the dedicated artist was continuous. He believed that the artist's task gets harder as he becomes more critical. He said, "Yes one paints more easily after many years, and problems are more easily solved, but one demands more of oneself. The layman, the amateur is more easily satisfied."

"Through the windows of this room," Karl said, during the winter, "I can see the bare limbs of a maple, a power pole with glass insulators, the sky beyond it and between the pattern of the wires, the cross pieces of the pole. The web of small maple branches tremble in the wind. The sunlight illuminates part of the house across the street, and the strong shadow of a roof lies against the other part which I can see from where I stand. It all makes an interesting complex pattern; I am absorbed; I find it lovely. Shall I take a microphotograph of the glass insulator or the section of the tree trunk and make it miscroscopic? I'd doubtless see wonders. But 
I see wonders now. I'm not bored with the visible world.

Karl said,

No good painter was ever 'realistic.' Every generation has had chaos. The visible world is still full of flowers, faces, skies, fields, apples, hills, as it was in the world of Cezanne and Pouissin. It is the painter-artist's job to make order: where Nature is profuse, complicated, chaotic, he simplifies. The truth is, that in many cases, the painter today either despises or fears Nature; often he will have none of her; no part. Man alone and man's inner cosmos interests him, preferably his own inner cosmos which since it is fascinating to him must therefore be fascinating to everyone else; he has more imagination and sensitivity than any one else. There are of course the painters who justify their ignoring of Nature by saying that everything is Nature; the hand that holds the brush that holds the paint that makes the stroke. This is one of the more common rationalizations.

Jane Austen lived in a time of turmoil, but did not reflect this in her work. Should she have? Artists are supposed to reflect their times. But no one says what part of their times. Every artist has his own angle from which he looks at the world, his world. About what did Bottecelli reflect? One might answer that he was a maverick. But so are many painters and writers.

Karl said, "What about Cezanne? Did he in his flowers, apples, landscapes, paint his world? Yes, what he found in his time that interested him."

Recently a critic, in on the whole a favorable review of Karl's work, wrote that he was a regionalist. We were amused; Karl had, for years, during the reign of regionalism, fought its narrowness. I toyed for a few minutes with the idea of writing the critic a letter, asking if he thought Cezanne a regionalist because he painted the landscape he was interested in and which he knew.

Although he was stricken with arteriosclerosis, Karl remained active and alert in his last years. Mary wrote of those years:

Our life went on much as it had before except that we could no longer take walks. People had us over. We had people over. Karl drew or painted. We talked of death. We talked about Karl's work. We talked of the past, the present and the near future.

In good weather Karl went out sketching with a group of friends. A small boy watching him draw on such a day said, "That's not the way lowa looks to me."

Karl said, "You are looking at lowa with your eyes. I am looking 


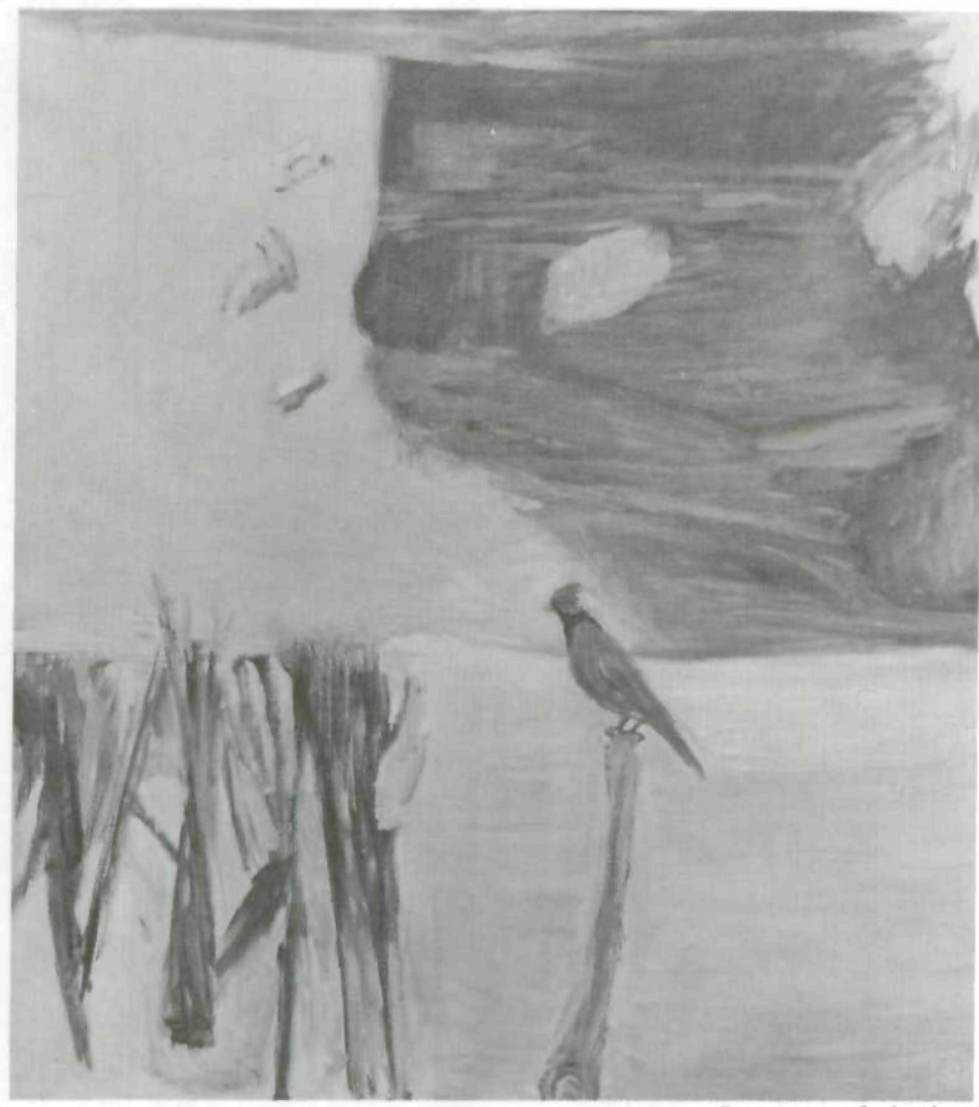

Courtesy of Author

Bird in Landscape, oil painting by Karl Mattern, finished a few hours before his death, January 18, 1969.

at it with mine. And this is my piece of paper." He smiled as he said this; the boy smiled and nodded.

Another day we went to the Art Center [in Des Moines]. After looking at a very bad painting Karl said, "Some painters think painting is only done with a brush and paint, that there is no demand on the brain."

On the last day of his life he finished a joyous landscape. He was happy about it. A few hours later while talking and laughing with two painters just outside the Des Moines Art Center he said, "Suddenly I am struck down," and he died. 
Copyright of Annals of Iowa is the property of State of Iowa, by \& through the State Historical Society of Iowa and its content may not be copied or emailed to multiple sites or posted to a listserv without the copyright holder's express written permission. However, users may print, download, or email articles for individual use. 